\title{
Slug/ $\beta$-Catenin-Dependent Proinflammatory Phenotype in Hypoxic Breast Cancer Stem Cells
}

\author{
Gianluca Storci, ${ }^{* \dagger}$ Sara Bertoni, ${ }^{\dagger}$ Sabrina De Carolis, ${ }^{\dagger \dagger}$ Alessio Papi, ${ }^{\ddagger}$ Marina Nati, ${ }^{*}$ Claudio Ceccarelli, ${ }^{*}$ Chiara Pirazzini, ${ }^{*}$ \\ Paolo Garagnani, * Alberto Ferrarini, ${ }^{\S}$ Genny Buson, ${ }^{\S}$ Massimo Delledonne, ${ }^{\S}$ Michelangelo Fiorentino, " Elisa Capizzi, \\ Elisa Gruppioni, "Mario Taffurelli, " Donatella Santini, Claudio Franceschi, ${ }^{*}$ Giuseppe Bandini, ** Francesca Bonifazi, ${ }^{* *}$ and \\ Massimiliano Bonafé ${ }^{\star \dagger}$
}

\begin{abstract}
From the Department of Experimental, Diagnostic and Specialty Medicine, ${ }^{*}$ the Center for Applied Biomedical Research, ${ }^{\dagger}$ the Pathology Unit, ${ }^{\Uparrow}$ Addarii Institute of Oncology, and the Institute of Haematology "L\& A Seragnoli", ** St. Orsola-Malpighi University Hospital, Bologna; the Departments of Biological, Geological and Environmental Sciences ${ }^{\ddagger}$ and Biotechnologies, ${ }^{\S}$ Functional Genomics Center, University of Verona, Verona; and the Department of Medical and Surgical Sciences," University of Bologna, Bologna, Italy
\end{abstract}

Accepted for publication July 30, 2013.

Address correspondence to Massimiliano Bonafé, M.D., or Gianluca Storci, Ph.D., Department of Experimental, Diagnostic and Specialty Medicine, University of Bologna, Bologna, Italy. E-mail: massimiliano.bonafe@unibo.it or gianluca.storci@unibo.it.

\begin{abstract}
Cancer stem cell survival relies on the activation of inflammatory pathways, which is speculatively triggered by cell autonomous mechanisms or by microenvironmental stimuli. Here, we observed that hypoxic bone marrow stroma-derived transforming growth factor- $\beta 1$ promotes the growth of human breast cancer stem cells as mammospheres. The ensuing Slug-dependent serine 139 phosphorylation of the DNA damage sensor H2AX in breast cancer stem cells induces tumor necrosis factor- $\alpha$ and IL-8 mRNAs, whose stability is enhanced by cytoplasmic $\beta$-catenin. $\beta$-Catenin also up-regulates and binds miR-221, reducing the stability of the miR-221 targets Rad51 and ER $\alpha$ mRNAs. Our data show that the Slug/ $\beta$ catenin-dependent activation of DNA damage signaling triggered by the hypoxic microenvironment sustains the proinflammatory phenotype of breast cancer stem cells. (Am J Pathol 2013, 183: 1688-1697; http:// dx.doi.org/10.1016/j.ajpath.2013.07.020)
\end{abstract}

Cancer stem cells (CSCs) constitute a minor population of immunophenotypically identifiable cells endowed with high tumor-initiating capability in xenografts. ${ }^{1}$ Recent literature shows that CSCs are endowed with a proinflammatory phenotype. $^{2-4}$ This feature is characterized by the overactivation of $\mathrm{NF}-\kappa \mathrm{B}-$ regulated proinflammatory cytokines [IL-6, tumor necrosis factor- $\alpha$ (TNF- $\alpha$ ), and IL-8], which are potent breast CSC growth factors. ${ }^{5-8}$ Notably, CSC survival and self-renewal rely on the activity of inflammatory pathways to a higher extent than in their normal counterpart. $^{2,9}$ Such an inflammatory addiction is currently investigated as a potential Achilles' heel of CSCs. ${ }^{2}$

The CSC phenotype is promoted by exposure to low oxygen tension. ${ }^{10,11}$ Hypoxic tissue regions, which frequently occur in the tumor mass, ${ }^{12}$ are currently regarded as the niches for CSCs. ${ }^{13}$ Intriguingly, the bone marrow, a privileged soil for metastatic breast cancer cell engraftment, ${ }^{14}$ harbors an oxygen-poor compartment enriched in hematopoietic stem cells niches. ${ }^{15}$ Conceivably, this may constitute a niche also for disseminating breast cancer cells.
Hypoxia promotes genetic instability and down-regulates $R A D 51$, the major player of the homologous recombination DNA repair pathway. ${ }^{16}$ Hypoxia also up-regulates the polycomb 2 receptor complex component EZH2, an acknowledged $R A D 51$ transcriptional repressor. ${ }^{17}$ Interestingly, EZH2 overexpression enhances breast CSCs self-renewal, ${ }^{17}$ similarly to the knockdown of the genome integrity gatekeeper $B R C A 1 .{ }^{18}$ Intriguingly, DNA-damaged cells cast inflammatory signals into the surrounding microenvironment. $^{19-21}$ Hence, a close relationship between the activation of the DNA damage response and the proinflammatory status in CSCs can be hypothesized.

Here, we show that hypoxic bone marrow stroma (BMH)derived transforming growth factor- $\beta 1$ (TGF- $\beta 1$ ) expands breast CSCs as mammospheres (MS). TGF- $\beta 1$ has been

Supported by grant PRIN 2008KTRN38 "Clinical, diagnostic and therapeutic implications of studies on breast cancer stem cells" (M.T. and M.B.) and by RFO funds ex $60 \%$, Cornelia Pallotti and Roberto Pallotti Foundation (M.B.). 
previously described as autocrine breast CSCs' promoting factor $^{22}$ : here, we report that the peptide induces an autocrine loop of TNF- $\alpha$, a previously identified CSC growth factor. ${ }^{3,23,24}$ We describe the ensuing up-regulation of the transcriptional repressor Slug, a master regulator of breast cancer and mammary gland stem cell self-renewal and survival. ${ }^{25-28}$ Slug engenders the serine 139 phosphorylation of the DNA damage sensor H2AX $(\gamma-\mathrm{H} 2 \mathrm{AX}),{ }^{29}$ and the $\mathrm{NF}-\kappa \mathrm{B}-$ mediated up-regulation of proinflammatory peptides IL-8 and TNF- $\alpha$, in the absence of any detectable genomic alteration. In MS, the Slug-dependent up-regulation of IL- 8 and TNF- $\alpha$ expression also relies on the recently characterized capability of $\beta$-catenin, a crucial modulator of stem cell features, ${ }^{30}$ to bind and stabilize mRNAs. ${ }^{31}$ On exposure to hypoxia, $\beta$-catenin interacts with the NF- $\kappa \mathrm{B}$ target miR-221, which has been previously associated with breast cancer cell aggressiveness. ${ }^{32,33} \beta$-Catenin then affects the mRNA stability of two miR-221 targets the DNA repair gene $\operatorname{Rad} 51^{34}$ and estrogen receptor- $\alpha(\mathrm{ER} \alpha)$. These data disclose that the Slug/ $\beta$-catenin proinflammatory phenotype in CSCs is a consequence of the hypoxia-induced activation of DNA damage response.

\section{Materials and Methods}

\section{Cell Lines and Chemicals}

MCF7 cells were grown as adherent layer in RPMI 10\% fetal bovine serum (Euroclone, Milan, Italy). MS were generated from MCF7 cells in mammary epithelial growth medium (MEGM), supplemented with ad hoc aliquots of B27, epidermal growth factor, basic fibroblast growth factor, insulin, and hydrocortisone (Lonza, Basel, Switzerland). ${ }^{7}$ Briefly, $5 \times 10^{3}$ MCF7 cells were filtered through a 40- $\mu \mathrm{m}$ nylon mesh (Becton Dickinson, Franklin Lakes, NJ) and suspended with $1 \mathrm{~mL}$ of complete MEGM in $1.5-\mathrm{cm}^{2}$ ultralow attachment wells (Corning, Corning, NY). MS were scored at day 5. Normoxic cultures were kept at $37^{\circ} \mathrm{C}$ in a 5\% $\mathrm{CO}_{2}$-humidified atmosphere. Hypoxia $\left(1 \% \mathrm{pO}_{2}, 5 \% \mathrm{pCO}_{2}\right.$, $94 \% \mathrm{pN}_{2}$ ) was obtained in an Invivo 2300 Hypoxia Workstation (Ruskinn Technology, Bridgend, UK). Recombinant human TNF- $\alpha$ and TGF- $\beta 1$ were purchased from SigmaAldrich (St. Louis, MO). Monoclonal neutralizing antibodies were anti-TNF- $\alpha$ antibody (clone 28401; R\&D Systems, Minneapolis, MN) and anti-TGF- $\beta 1$ antibody (clone 9016-2; Sigma-Aldrich).

\section{MS Generation from Breast Cancer Tissues and Isolation of Fibroblasts from the Normal Bone Marrow}

MS were generated in complete MEGM from human breast carcinoma tissues that were characterized according to standard diagnostic procedures ${ }^{3,7}$ (Supplemental Table S1). The procedure had been approved by the St. Orsola-Malpighi University Hospital ethical committee (Prot n.75/2011). Immunohistochemistry was performed with anti-human ER (clone SP1), anti-human progesterone receptor (PgR; clone 1E2), and anti-human epidermal growth factor receptor 2 (HER2; Pathway clone 4B5) from Ventana Medical Systems, Tucson, AZ. Immunostaining was performed on a Ventana Benchmark Ultra immunostainer and visualized using the UltraView DAB Universal Detection Kit. To assess selfrenewal, MS were disaggregated at day 7 in $1 \times$ trypsinEDTA (STEMCELL Technologies, Vancouver, BC, Canada), washed in complete MEGM, filtered throughout a 40- $\mu \mathrm{m}$ nylon mesh, and seeded to form higher (second, third, and fourth) generation MS. Fibroblasts were isolated from bone marrow from one healthy donor. Adherent mononuclear cells were cultured in Dulbecco's minimal essential medium and supplemented with $20 \%$ fetal bovine serum for 3 weeks. Second-passage fibroblasts were grown at $75 \%$ confluence in hypoxic conditions, and culture supernatants were collected after 24 hours. Written informed consent was obtained for primary cell isolation.

\section{Generation of Slug and $\beta$-Catenin MCF7 Knockdown and of Slug Overexpressing MCF7 Clones}

Stable Slug knockdown (shSlug) MCF7 cells has been previously described. ${ }^{7}$ Stable knockdown of $\beta$-catenin (shBeta) in MCF7 cells was obtained via the retroviral transduction of pCtoGMB retroviral vector carrying human $\beta$-catenin-specific 19-nt coding sequence (5'-GAGCCTCTATACCACCCAC- $3^{\prime}$ ), as previously described. ${ }^{7}$ Slug overexpressing (Babe-Slug) MCF7 clones were generated from the BamHI/EcoRI full-length Slug cDNA, and then subcloned into the pBabe-Puro retroviral vector (pBabeSlug). Babe-Slug cells were selected in RPMI containing 1 $\mathrm{mg} / \mathrm{mL}$ puromycin and then seeded into 96-well plates for single-cell cloning. Three Babe-Slug MCF7 clones (A, B, C) were used for the study.

\section{Transient Transfection of siRNA, PremiR, and AntagomiR}

siRNA against H2AX-, SLUG-, and GC-matched scrambled control (Life Technologies, Carlsbad, CA) were transiently transfected with Lipofectamine 2000 (Life Technologies) to adherent MCF7 cells $\left(10^{5}\right.$ cells $\times 3 \mathrm{~cm}^{2}$ well $)$, or with jetPEI (Polyplus, Illkirch, France) to MS, at a concentration of $1 \mu \mathrm{g} /$ well for 72 hours. Pre- and antagomiR-221 (Life Technologies) were transiently transfected to adherent MCF7 cells $\left(10^{5}\right.$ cells $\times 3 \mathrm{~cm}^{2}$ well $)$ at a concentration of $100 \mathrm{pmol} /$ well for 72 hours.

\section{Luciferase Reporter Assay}

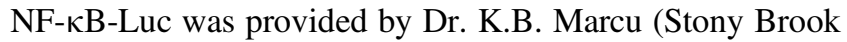
University, Stony Brook, NY); Slug-Luc reporter vector was provided by Dr. Togo Ikuta (Saitama Cancer Centre, Saitama, Japan); TOPFLASH reporter vector was provided by Dr. Rolf Kemler (Max Planck Institute, Heidelberg, 
Germany). Luciferase reporters were assessed using the Dual-Luciferase Reporter Assay System and a GloMax 20/ 20 Luminometry System (Promega, Madison, WI).

\section{RT-PCR and Real-Time PCR analysis}

Total RNA was extracted from cells using TRIzol reagent according to the manufacturer's instructions (Life Technologies). RT-PCR primers were TNF- $\alpha$ : forward $5^{\prime}$-GGCCCAGGCAGTCAGATCAT- $3^{\prime}$ and reverse $5^{\prime}$-GGGGCTCTTGATGGCAGAGA-3' (310 bp); IL-8: forward 5'GCTTTCTGTGGAAGAGAGC-3', and reverse 5'-GGCACAGTGGAACAAGGACT-3' (606 bp); Rad51: forward 5'GCCTGCTGGAGAGAGGA-3', and reverse 5'-GGAAGCTGGCAGGTGAC-3' (500 bp); ER $\alpha$ : forward 5'-TGAAAGGTGGGATACGAAAAGAC- ${ }^{\prime}$, and reverse $5^{\prime}$-CAGGATCTCTAGCCAGGCACAT-3' (410 bp); real-time probes for GUS ( $\beta$-glucuronidase, 4326320E), Slug (Hs00950344m1), IL-8 (Hs00174103-m1), TNF- $\alpha$ (Hs00174128-m1), Brca1 (Hs01556193-m1), Rad51 (Hs00153418-m1), ER $\alpha$ (Hs 01046818-m1), TGF- $\beta$ receptor 1 (TGF $\beta$-R1) (Hs100998133m1), EZH2 (Hs001016789-m1), and miR-221 (TM000524) were obtained from Life Technologies.

\section{Actinomycin D mRNA Stability Assay}

A mRNA stability assay was performed exposing MCF7 and shBeta MCF7 cells to actinomycin D at a concentration of $100 \mathrm{ng} / \mathrm{mL}$ (Sigma-Aldrich) and assessed by RT-PCR at different time points. The first time point was taken as the reference value for each time series.

\section{ELISA}

The EZH2 enzyme-linked immunosorbent assay (ELISA) was purchased from Epigentek (Brooklyn, NY) and performed following the manufacturer's instructions.

\section{Western Blot Analysis}

Proteins were extracted with radioimmunoprecipitation assay buffer, with the exception of $\gamma-\mathrm{H} 2 \mathrm{AX}$ extraction, which was performed by adding $\mathrm{HCl}$ to the lysis buffer $[10$ $\mathrm{mmol} / \mathrm{L}$ HEPES (pH 7.9); $1.5 \mathrm{mmol} / \mathrm{L} \mathrm{MgCl}_{2} ; 10 \mathrm{mmol} / \mathrm{L}$ $\mathrm{KCl}$ ] to a final concentration of $0.2 \mathrm{~mol} / \mathrm{L}$. Sixty to $100 \mu \mathrm{g}$ of proteins were assessed by Western blot analysis, using the following antibodies: anti-Rad51 (clone 3C10) and anti-phospho-ser 139-H2AX (clone JBW301; Millipore, Billerica, MA); anti-Slug (clone L40C6; Cell Signaling Technology, Danvers, MA); and anti- $\beta$-catenin (E5) and anti-Actin (C4; Santa Cruz Biotechnology, Santa Cruz, CA).

\section{mRNA Immunoprecipitation Assay}

A mRNA immunoprecipitation assay was performed following a previously published protocol. ${ }^{35}$ In brief, cultured cells were suspended in lysis buffer $[100 \mathrm{mmol} / \mathrm{L} \mathrm{KCl}$, $5 \mathrm{mmol} / \mathrm{L} \mathrm{MgCl}_{2}, 10 \mathrm{mmol} / \mathrm{L}$ HEPES ( $\mathrm{pH} 7.0$ ), $0.5 \%$ Nonidet P-40] supplemented with RNase and protease inhibitors. Proteins were immunoprecipitated using protein A beads (Santa Cruz Biotechnology) and either anti- $\beta$ catenin (E5; Santa Cruz Biotechnology) or anti-HuR (Molecular Probes, Eugene, OR), or normal IgG (sc-2025; Santa Cruz Biotechnology) mouse antibodies in NT-2 buffer [50 mmol/L Tris (pH 7.4), $150 \mathrm{mmol} / \mathrm{L} \mathrm{NaCl}, 1 \mathrm{mmol} / \mathrm{L}$ $\mathrm{MgCl}_{2}, 0.05 \%$ Nonidet P-40], supplemented with RNase inhibitor $(40 \mathrm{U} / \mu \mathrm{L})$, and dithiothreitol $(1 \mathrm{mmol} / \mathrm{L})$. Immunoprecipitates were resuspended in TRIzol reagent (Life Technologies). mRNA was assessed by RT-PCR analysis (IL-8 and TNF- $\alpha$ ) or real-time PCR (miR-221). Data were expressed as the fold increase of each mRNA level bound to mouse-specific antibody over the amount of the same mRNA bound to normal mouse IgG.

\section{Microsatellite Instability}

Microsatellite instability analysis was performed through PCR reaction (Life Technologies, Foster City, CA), using the CC-MSI kit (AB Analitica, Padova, Italy), which allows the amplification of 10 markers (BAT25, BAT26, D2S123, D5S346, D17S250, NR21, NR24, BAT40, TGF3-RII, and D18S58) in two separate reactions. The fluorescent PCR products were analyzed in an ABI 3730XLDNA analyzer using the GeneMapper software version 4.0 (Life Technologies).

\section{In Situ Hybridization Analysis}

Fluorescence in situ hybridization analyses for chromosome 1 and 6 copy number variations were performed on paraformaldehyde-fixed/paraffin-embedded cell pellets using centromeric probes CEP1 (D1Z5 Spectrum Orange Probe) and CEP6 (D6Z1 Spectrum Green Probe) from Abbott Laboratories (Des Plaines, IL). Twenty nonoverlapping nuclei were counted at $\times 1000$ magnification and examined using a Nikon Eclipse 80i microscope (Nikon Corporation, Tokyo, Japan). The cutoff value for each probe was set equal to the means $\pm 3 \mathrm{SD}$ of the control values. Dual-color silver/chromogenic in situ hybridization analysis for HER2 gene status and chromosome 17 copy number variations was performed by INFORM HER2 Dual ISH DNA Probe Cocktail (Ventana Medical Systems/Roche Diagnostics, Mannheim, Germany). Twenty nonoverlapping nuclei were counted at $\times 600$ magnification.

\section{Shotgun Whole-Genome Sequencing}

DNA library preparation was performed according to the Illumina TruSeq DNA Sample Prep protocol (Illumina, San Diego, CA). A total amount of $2.5 \mu \mathrm{g}$ of genomic DNA was sonicated to obtain 400-bp fragments, an end-repair step was performed, and an A nucleotide was added to the $3^{\prime}$ blunt ends before ligating multiple indexing adapters to the DNA 
A

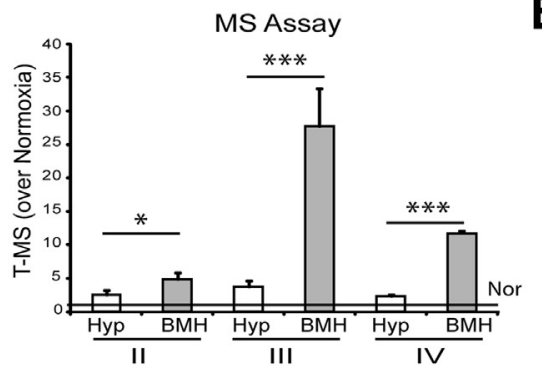

B

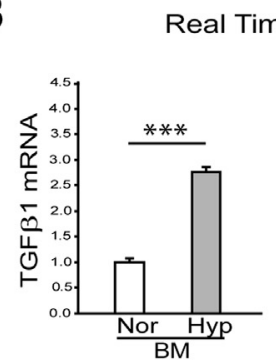

Real Time PCR

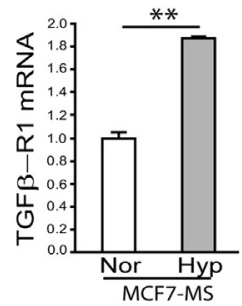

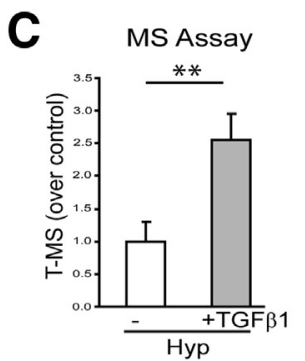
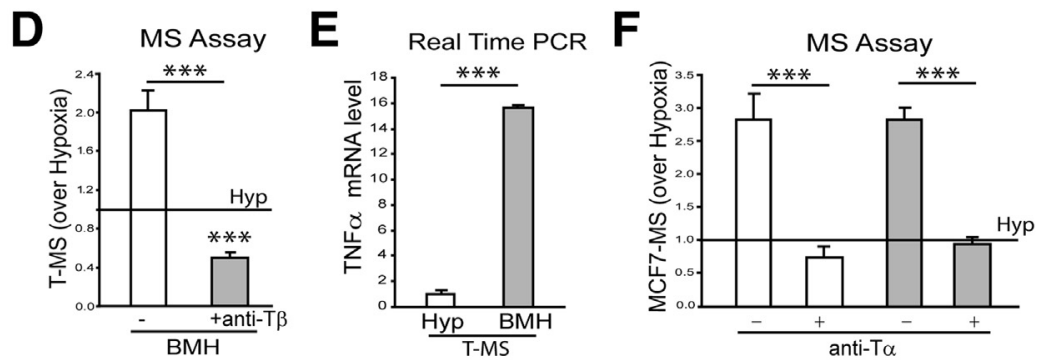

Figure 1 Hypoxic BMH supernatants enhance MS self-renewal via paracrine TGF $\beta 1$ /autocrine TNF- $\alpha$ crosstalk. A: Second- (II, $n=3$, samples S1, S3, S4), third- (III, $n=1$, sample S4), and fourth- (IV, $n=1$, sample S4) generation tumor-derived mammospheres (T-MS) assay on exposure to either $1 \% \mathrm{pO}_{2}$ [hypoxic (Hyp)] or BMH supernatants. Normoxic (Nor) T-MS formation is shown as baseline. B: Real-time PCR analysis of TGF- $\beta 1 \mathrm{mRNA}$ in Nor and Hyp BMH cells, and of TGF $\beta$-R1 expression in Nor/Hyp MCF7-MS. C: T-MS assay (sample S2) in response to hypoxia in presence/absence of $15 \mathrm{ng} / \mathrm{mL}$ TGF- $\beta 1$. D: T-MS assay (sample S2) on BMH supernatants in presence/absence of $1.5 \mu \mathrm{g} / \mathrm{mL}$ TGF- $\beta 1$ neutralizing antibody (anti-T $\beta$ ); Hypoxic T-MS formation is shown as baseline. E: Real-time PCR analysis of TNF- $\alpha$ mRNA level in T-MS (sample S3) on BMH supernatants; F: MCF7 MS assay on exposure to either BMH supernatants (white bars) or $15 \mathrm{ng} / \mathrm{mL} \mathrm{TGF}-\beta 1$ (gray bars), in the presence/absence of $1.5 \mu \mathrm{g} / \mathrm{mL} \mathrm{TNF}-\alpha$ neutralizing antibody (anti-T $\alpha$ ); hypoxic T-MS formation is shown as baseline. Data are presented as means \pm SD. ${ }^{*} P=0.05,{ }^{*} P<0.01$, and ${ }^{* *} P<0.001$.

fragments. The adapter-ligated DNA fragments were sizeselected from gel, and DNA fragments with adapters on both ends were selectively enriched using 10 cycles of PCR. Libraries were pooled and sequenced using the Illumina HiSeq 1000 sequencing system and applying standard Illumina protocols with the TruSeq SBS Kit v3-HS and TruSeq PE Cluster Kit v3-cBot-HS kits (lllumina). Cell ploidy was evaluated as the ratio between the number of reads of each sample over the reference genome, using a window of $1 \times 10^{5}$ bases.

\section{Bioinformatics and Statistics}

Bioinformatics analysis on AU-rich (adenylate uridylaterich) element-containing mRNA was performed on the online database AREsite (http://rna.tbi.univie.ac.at/cgi-bin/AREsite. $c g i$, last accessed July 31, 2012). miRNA structure was estimated by the mfold Web Server (The RNA Institute, http:// mfold.rna.albany.edu, RNA Folding Form, version 2.3, last accessed September 28, 2012). Statistical analysis was performed using SPSS software version 10 (IBM, Armonk, New York). $P$ values referring to $t$-test are reported.

\section{Results}

\section{Hypoxic Bone Marrow Stromal Cells Enhance MS Formation via TGF- $\beta 1$-Induced Autocrine TNF- $\alpha$ Loop}

Hypoxia triggers stem cell features and pathways in cancer cells. ${ }^{6,11,13}$ To reproduce in vitro the hypoxic niche environment, we generated hypoxic MS in presence/absence of hypoxic BMH supernatants. We observed that BMH conferred an increase in MS formation, compared to hypoxia alone (Figure 1A). To gain an insight into this phenomenon, we availed ourselves of our recent observation that breast cancer-associated mammary gland fibroblasts trigger MS formation via TGF- $\beta 1$ secretion. ${ }^{3}$ We detected increased expression of TGF- $\beta 1$ mRNA in hypoxia-exposed $\mathrm{BMH}$ fibroblasts and of TGF $\beta$-RI mRNA in hypoxiaexposed MS (Figure 1B). These data prompted us to test the hypothesis that TGF- $\beta 1$ signaling is enhanced in the hypoxic stromal niche. We found that TGF- $\beta 1$ consistently increased hypoxic MS generation (Figure 1C), and that TGF- $\beta 1$ neutralizing antibody hampered the BMH supernatant-induced MS formation (Figure 1D). In keeping with these results, we observed that hypoxic BMH supernatants triggered TNF- $\alpha$ expression in MS (Figure 1E). Finally, the capability of BMH supernatants and TGF- $\beta 1$ to increase MS formation was tapered by TNF- $\alpha$ neutralizing antibody (Figure 1F). These data show that hypoxic BMH induce CSC's autocrine TNF- $\alpha$ loop via TGF- $\beta 1$.

\section{Slug Overexpression Blunts Rad51 Expression and Induces H2AX Serine 139 in Absence of DNA Damage}

Slug is a hypoxia-induced regulator of mammary gland stem cells. $^{24}$ We observed that hypoxic TGF- $\beta 1$ and BMH supernatants engendered Slug up-regulation in MS, and that BMH supernatant-induced MS formation was drastically 
hampered in Slug shRNA-infected (MCF7-shSlug) MCF7 cells and in Slug siRNA-transfected tumor derived mammospheres (T-MS) (Supplemental Figure S1, A and B). Hypoxia has been shown to down-regulate the expression of Rad51 in cancer cells. ${ }^{16}$ We thus aimed to explore the molecular relationship between Slug and Rad51 expression in hypoxic MS. We observed a TNF- $\alpha$-dependent downregulation of Rad51 in hypoxic MCF7 cells, coupled with the increase in serine 139-phosphorylated $\mathrm{H} 2 \mathrm{AX}(\gamma-\mathrm{H} 2 \mathrm{AX})$, an early sensor of DNA damage ${ }^{29,34}$ (Figure 2A). Interestingly, Rad51 down-regulation turned out to be negligible when MCF7-shSlug cells were examined (Figure 2B). The stable transfection of MCF7 cells with pBabe-Slug vector allowed us to generate Slug-overexpressing MCF7 clones (pBabe-SlugA, -SlugB, -SlugC). In such cells, we found enhanced MS generation compared to controls (Supplemental Figure S1C). In pBabe-Slug clones, we then confirmed the capability of Slug to hamper Rad51 expression and to trigger $\gamma-\mathrm{H} 2 \mathrm{AX}$ expression (Figure 2C). It is noteworthy that despite such $\gamma-\mathrm{H} 2 \mathrm{AX}$ activation, pBabe-Slug clones carried the same microsatellite pattern of control cells (Supplemental Figure S2A). Moreover, pBabe-Slug clones showed changes neither in the number of centromeric signals at chromosomes 1,6 , and 17 , nor in the amplification extent of HER2 locus (Figure 2D and
Supplemental Figure S2B). Even shotgun genomic sequence analysis failed to reveal any substantial genomic modification in Slug overexpressing clones (Figure 2E). These data show that Slug down-regulates the DNA repair protein $\operatorname{Rad} 51$ in TNF- $\alpha$-exposed hypoxic breast cancer cells. The ensuing activation of DNA damage signaling does not per se entail the accumulation of overt genetic damage.

\section{Slug Overexpression Drives the $\beta$-Catenin-Dependent Posttranscriptional Regulation of Proinflammatory Cytokine mRNAs}

Based on the results above, we tested the capability of TNF- $\alpha$ to induce its own mRNA, and we found that this phenomenon was hampered in shSlug-MCF7 MS (Figure 3A). This finding led us to conclude that Slug is required for the setup of the autocrine TNF- $\alpha$ loop in CSCs, and prompted us to investigate the mediators of such a proinflammatory phenotype. We observed that, despite the similar levels of NF- $\kappa \mathrm{B}$ activity in normoxic and hypoxic pBabe-Slug clones (Figure 3B), the NF- $\kappa$ B targets TNF- $\alpha$ and IL-8 mRNA were 100 -fold higher in hypoxic pBabe-Slug clones compared to the normoxic ones (Figure 3C). Moreover, despite the siRNAmediated H2AX (siH2AX) knockdown remarkably reducing
A

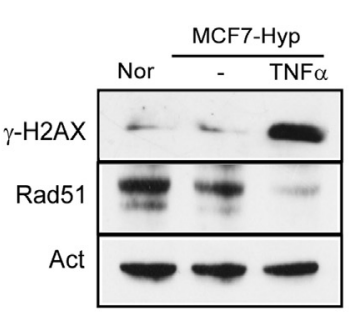

B

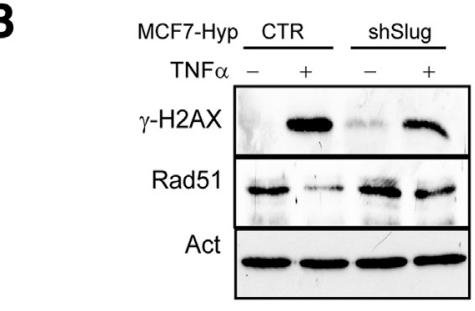

C

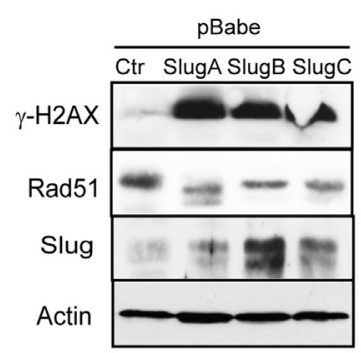

$D$
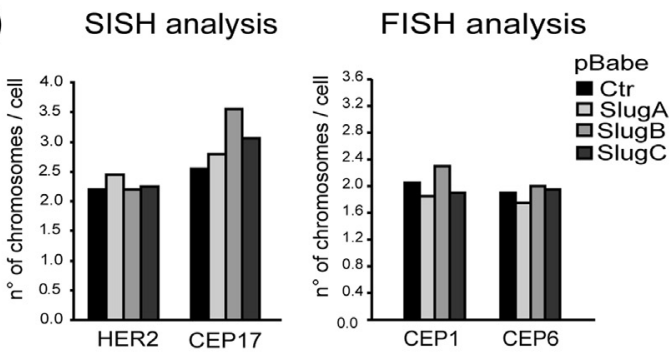

E

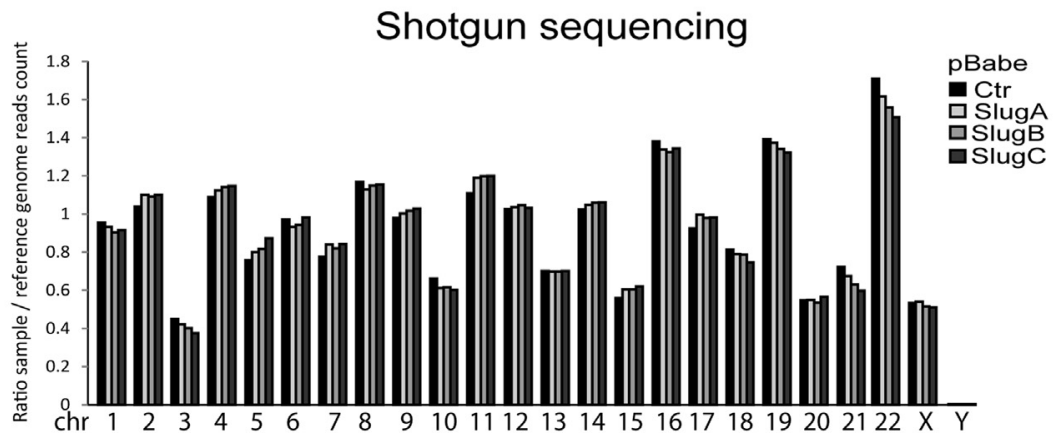

Figure 2 TNF- $\alpha$ /Slug axis-dependent Rad51 down-regulation and $\gamma-\mathrm{H} 2 \mathrm{AX}$ up-regulation in hypoxic breast cancer cells. A: Western blot analysis of $\gamma-\mathrm{H} 2 \mathrm{AX}$ and Rad51 in hypoxia-exposed breast cancer MCF7 (MCF7-Hyp) cells, in the presence/absence of $10 \mathrm{ng} / \mathrm{mL}$ TNF- $\alpha$ (24 hours). B: Western blot analysis of $\gamma$-H2AX and Rad51 in MCF7-Hyp transfected with empty (CTR) or shSlugencoding pCtoMB vector, in the presence/absence of $10 \mathrm{ng} / \mathrm{mL}$ TNF- $\alpha$ (24 hours). C: Western blot analysis of $\gamma-\mathrm{H} 2 \mathrm{AX}$, Rad51 protein level in empty (Ctr) or Slug pBabe-overexpressing clones (SlugA, SlugB, and SlugC). D: Silver/chromogenic in situ hybridization (SISH) and fluorescence in situ hybridization (FISH) analysis on HER2 and CEP17, and on CEP1 and CEP6 in Ctr/pBabe-Slug clones. E: Shotgun whole-genome sequencing analysis on $\mathrm{Ctr} / \mathrm{pBabe-Slug}$ clones; data are presented as means \pm SD. 
A

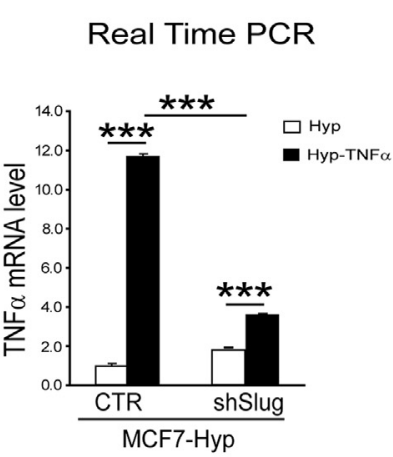

B

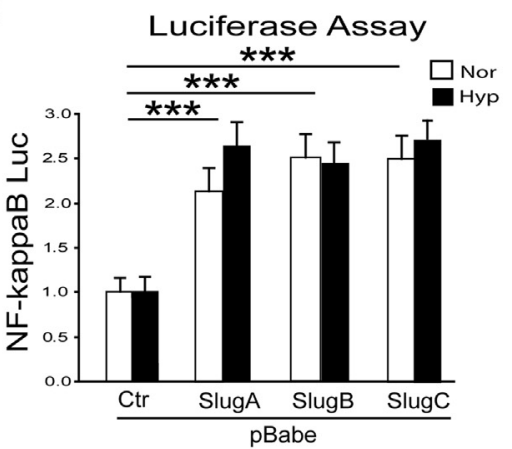

C

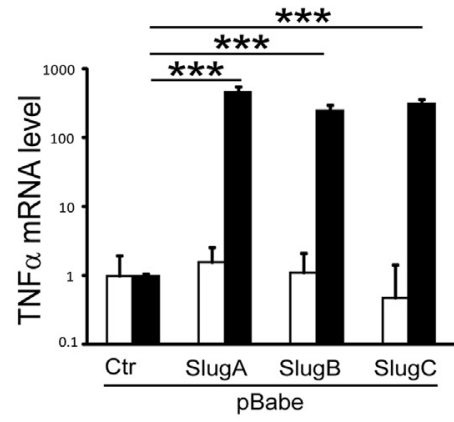

D

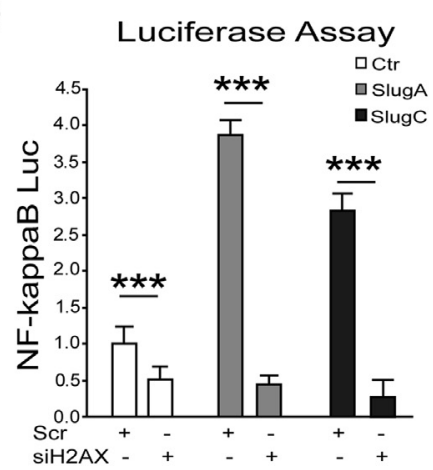

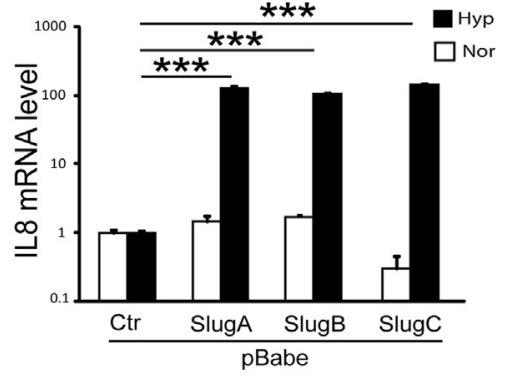

E

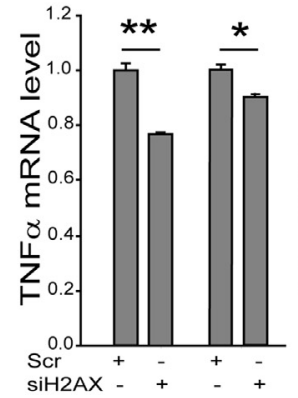

Real Time PCR

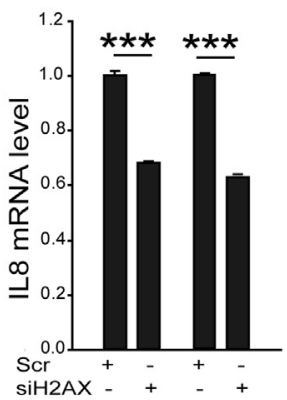

Figure $3 \quad \gamma-\mathrm{H} 2 \mathrm{AX}$-dependent proinflammatory phenotype in Slug-overexpressing breast cancer cells. A: Real-time PCR analysis of TNF- $\alpha$ mRNA level in breast cancer MCF7-Hyp CTR/shSlug cells in the presence/absence of $10 \mathrm{ng} / \mathrm{mL}$ TNF- $\alpha$ (24 hours). B: NF-KB luciferase (Luc) assay in normoxic and hypoxic pBabe-Ctr/SlugA, - B, -C clones. C: Real-time PCR analysis of TNF- $\alpha$ and IL-8 mRNA in normoxic and hypoxic pBabe-Ctr/SlugA, - B, - C clones. D: NF- $\kappa B L u c$ assay in hypoxic pBabe $\mathrm{Ctr} /$ SlugA and $-\mathrm{C}$ clones transfected $\mathrm{Scr} / \mathrm{H} 2 \mathrm{AX}$ siRNA (siH2AX). E: Real-time PCR analysis of TNF$\alpha$ and IL-8 mRNA levels in hypoxic pBabe-Ctr/ SlugA (left) and -B (right) clones, transfected with $\mathrm{Scr} / \mathrm{siH} 2 \mathrm{AX}$; data are presented as means \pm SD. ${ }^{*} P<0.05,{ }^{*} P<0.01$, and ${ }^{* * *} P<0.001$. the extent of NF- $\kappa$ B activity in pBabe-Slug cells (Figure 3D), siH2AX only slightly lowered TNF- $\alpha$ and IL-8 mRNA levels (Figure $3 \mathrm{E}$ ). We therefore reasoned that the NF- $\kappa \mathrm{B}$ transcriptional machinery in pBabe-Slug clones is coupled with posttranscriptional mechanisms that might control TNF- $\alpha$ and IL-8 overexpression under hypoxia.

$\beta$-Catenin is a nuclear stem-cell regulatory transcription factor that cooperates with Slug in a variety of biological mechanisms. $^{27,28,30}$ Cytoplasmic $\beta$-catenin has been recently shown to enhance mRNA stability by direct binding to mRNA $3^{\prime}$ untranslated regions (UTRs), in cooperation with the mRNA stabilizing protein HuR. ${ }^{36}$ Notably, we found similar transcriptional $\beta$-catenin activity, but increased cytoplasmic $\beta$-catenin in pBabe-Slug clones compared to controls (Supplemental Figure S3). We then documented potential $\beta$-catenin and HuR binding sites at TNF- $\alpha$ and IL-8 3'-UTR mRNA (Figure 4A). By means of mRNA immunoprecipitation assay, we demonstrated that $\beta$-catenin was bound to TNF- $\alpha$ and IL- 8 mRNA only on hypoxia, whereas HuR bound the mRNAs under normoxia and hypoxia (Figure 4B). We were then able to ascertain that TNF- $\alpha$ and IL- 8 mRNA stability were decreased in hypoxia-exposed MCF7-shBeta cells (Figure 4C). These data show that $\beta$-catenin contributes to the Slug-dependent proinflammatory status of hypoxic breast CSCs, by modulating mRNA stability, via $\beta$-catenin.

\section{Slug Overexpression Elicits $\beta$-Catenin-Dependent Posttranscriptional Regulation of Rad51}

The data also led us to investigate the role of $\beta$-catenin in the regulation of Rad51 expression. Bioinformatics analysis revealed that $\operatorname{Rad} 513^{\prime}$-UTR is a putative consensus for miR-221 (Supplemental Figure S4A). Accordingly, the transfection of premiR-221 elicited the decrease of Rad51 protein expression in hypoxic MCF7 MS (Supplemental Figure S4B). In keeping with data showing that miR-221 is transcriptionally up-regulated by Slug and $N F-\kappa B,{ }^{32,37}$ 
A

TNF $\alpha$ mRNA
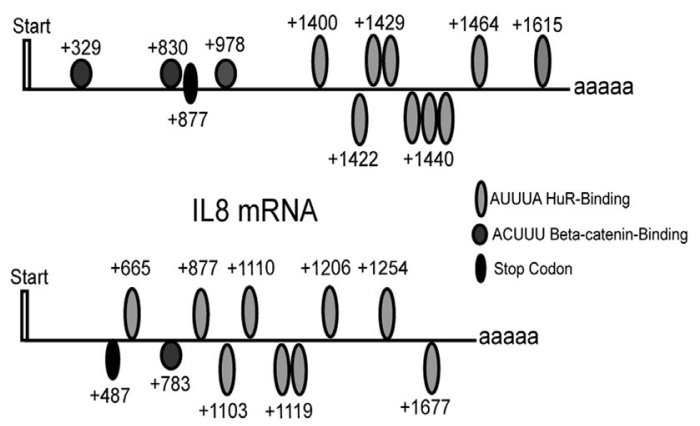

B

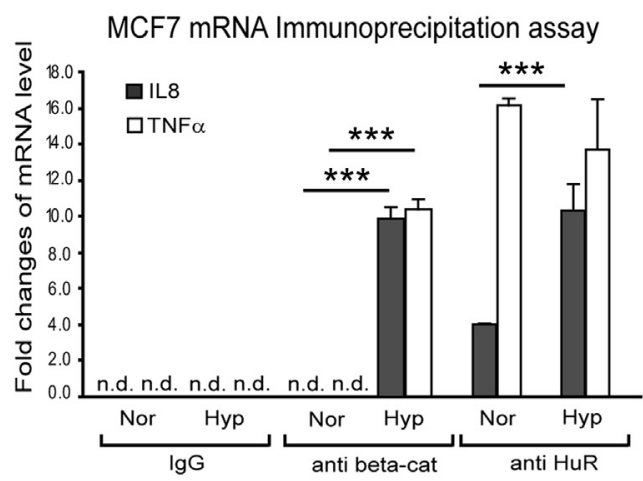

C

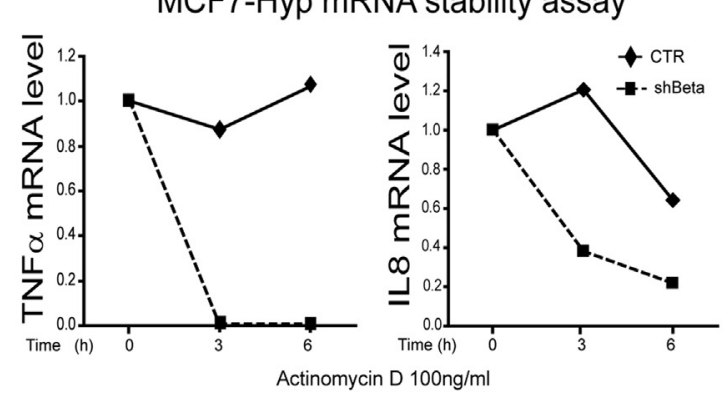

Figure $4 \quad \beta$-Catenin binds and stabilizes TNF- $\alpha$ and IL-8 mRNAs. A: Scheme showing TNF- $\alpha$ and IL- 8 mRNAs. $\beta$-Catenin and HuR binding sites are highlighted. B: TNF- $\alpha$ and IL- 8 mRNA immunoprecipitation assay in breast cancer MCF7 Nor/Hyp cells with mouse anti- $\beta$-catenin, anti-HuR, and IgG antibodies. C: TNF- $\alpha$ and IL-8 mRNA stability assay in MCF7-Hyp CTR/shBeta cells; data are presented as means \pm SD. Hyp, hypoxia; n.d., not detected; Nor, normoxia. ${ }^{* *} P<0.001$.

we observed that miR-221 was down-regulated in siH2AXtransfected pBabe-Slug clones (Figure 5A), as well as in shSlug and shBeta MCF7 cells (Supplemental Figure S4C). Owing to the presence of a $3^{\prime}$-ACUUU- $5^{\prime}$ sequence in the mature miR-221 that may potentially bind $\beta$-catenin (Supplemental Figure S4D), we tested the hypothesis that $\beta$-catenin might directly bind miR-221 and regulate Rad51 expression. We found that on hypoxia, but at a very limited extent under normoxia, miR-221 was immunoprecipitated by the $\beta$-catenin specific antibody (Figure 5B). We then were able to show that Rad51 mRNA stability and protein level were increased in hypoxic MCF7-shBeta cells (Figure 5, C and D). Similar data were obtained for ER $\alpha$ mRNA, which was stabilized in hypoxic MCF7-shBeta cells (Supplemental Figure S5A). Our data also confirmed that ER $\alpha$ is a target of miR-221, because ER $\alpha$ expression was increased by anti-miR-221 and decreased by premiR-221 administration (Asiedu et $\mathrm{al}^{38}$ ) (Supplemental Figure S5B). These data highlight the role of $\beta$-catenin/miR-221 circuitry in gene expression profile of Slug overexpressing cells.

\section{Discussion}

This paper started with the observation that hypoxic BMH engender a TNF- $\alpha$-driven Slug/ $\beta$-catenin axis, which promotes the self-renewal of breast CSCs. In particular, hypoxia elicits TGF- $\beta 1$ expression in stromal cells and TGF $\beta$-R1 in MS, thus facilitating the activation of the pathway, which is expected to be less active (or even latent) in the absence of hypoxia. It is noteworthy that we have recently found that tumor-associated, but not normal, breast fibroblasts enhance MS formation via a similar paracrine/ autocrine TGF- $\beta 1 /$ TNF- $\alpha$ interplay. ${ }^{3}$ TGF- $\beta 1$ has been described as a potent breast CSC autocrine growth factor ${ }^{22}$ In turn, the growth-promoting activity of TNF- $\alpha$ on human MS has been previously reported. ${ }^{23,24}$ Intriguingly, the two mediators elicit overt stem cell features when coadministered to breast cancer cells. ${ }^{39}$ These data support the notion
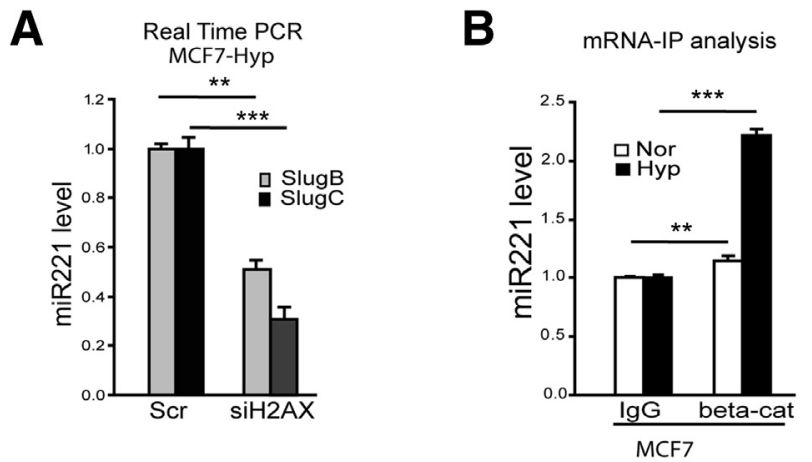

C

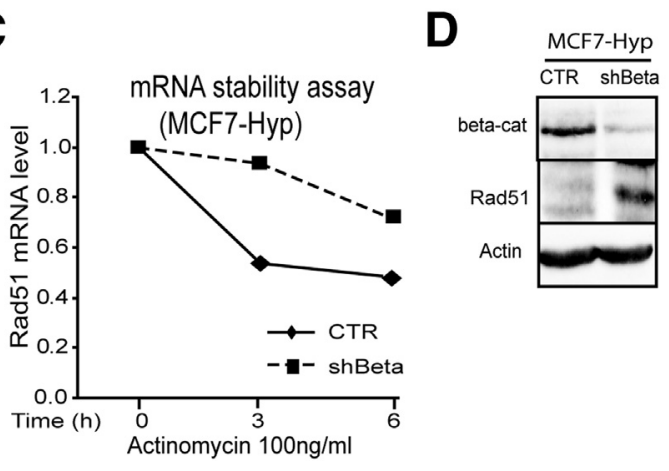

Figure 5 The $\beta$-catenin/miR-221 interplay posttranscriptionally downregulates Rad51 expression. A: Real-time PCR analysis of miR-221 in hypoxic pBabe-Ctr/SlugB, -C clones, transfected with Scr/siH2AX. B: mRNA immunoprecipitation (IP) assay of miR-221 level in breast cancer MCF7 Nor/Hyp cells with mouse IgG and anti- $\beta$-catenin antibodies. C: Rad51 mRNA stability assay in MCF7-Hyp CTR/shBeta cells. D: WB analysis of $\beta$-catenin and Rad51 in MCF7-Hyp CTR/shBeta cells; data are presented as means \pm SD. Hyp, hypoxia; Nor, normoxia. ${ }^{* *} P<0.01,{ }^{* *} P<0.001$. 
that such different environmental stimuli converge on the induction of the breast CSC phenotype.

Slug is a crucial regulator of mammary gland stem cell functioning. ${ }^{28}$ Published data show that Slug is a hypoxiainduced protein, and that it is a target of the TGF- $\beta 1$ and TNF- $\alpha$ pathways. ${ }^{7,40}$ Accordingly, we here demonstrate that Slug up-regulation follows the microenvironmental stimuli that pertain to the CSCs niche, ie, hypoxia and hypoxic stromal cell-derived peptides. Our data suggest that similar clues may be provided by the cancer-associated stroma ${ }^{3}$ and by the stromal cells to which CSCs disseminate and seed.

We then shed light on major observations that have been performed in the recent past. The former is the proinflammatory phenotype of breast $\mathrm{CSCs},{ }^{3}$ the latter is the association between the down-regulation of DNA repair genes and the enhancement of breast CSCs features. ${ }^{17}$

As far as the CSCs proinflammatory phenotype is concerned, we find that Slug expression up-regulates the level of the DNA damage sensor $\gamma$-H2AX. ${ }^{34}$ According to the notion that the activation of the DNA damage response pathway engenders the proinflammatory response, ${ }^{19,20}$ we show that the knockdown of the DNA damage sensor $\gamma-\mathrm{H} 2 \mathrm{AX}$ blunts $\mathrm{NF}-\kappa \mathrm{B}$ activity and the expression of inflammatory mediators. These data suggest that the proinflammatory phenotype of CSCs originates from the activation of the DNA damage sensing pathway. Consequently, the accrual of DNA damage can be expected to occur in such cells. On the contrary, although the onset of minor genomic alterations cannot be excluded, we did not detect any overt DNA damage in Slug overexpressing cells. In fact, $\gamma$-H2AX activation might occur independently from its activity as a DNA damage sensor. ${ }^{41,42}$ In particular, $\gamma-\mathrm{H} 2 \mathrm{AX}$ activation promotes angiogenesis and stem cell pool maintenance, two processes engendered by hypoxia. ${ }^{11,41,42}$ Therefore, we can conclude that the proinflammatory phenotype of breast CSCs, which is not per se associated with the onset of overt genomic abnormalities, relies on the activation of hypoxic DNA damage response. In regard to this issue, we show that hypoxia also enhances the mRNA stability of proinflammatory peptides via $\beta$-catenin. $\beta$-Catenin has long been recognized as a master controller of mammary gland stem cell homeostasis via its nuclear transcriptional activity. ${ }^{11,30}$ However, cytoplasmic $\beta$-catenin binds and stabilizes various cytoplasmic mRNA,${ }^{31}$ including Il-6 (G D'Uva, S Bertoni, M Lauriola, S De Carolis, A Pacilli, L D'Anello, D Santini, M Taffurelli, C Ceccarelli, Y Yarden, L Montanaro, M Bonafè, G Storci, unpublished data). In accordance with the notion that posttranscriptional mechanisms gain importance on hypoxia, ${ }^{43,44}$ the $\beta$-catenindependent stabilization of mRNAs becomes overt in hypoxia-exposed cells. Noteworthy, $\beta$-catenin triggers the inflammation-dependent aggressive behavior in hepatocellular carcinoma, suggesting that the results presented here may extend to other tumor types' where proinflammatory peptides may act as CSCs growth factors. ${ }^{5-8,44}$

With reference to the relationship between CSCs and the down-regulation of DNA repair genes, we convey that Slug down-regulates Rad51 expression. Slug is a transcriptional repressor that hinders the expression of the genome gatekeeper Brcal ${ }^{45}$ We show that the $\beta$-catenin/miR-221 interaction in Slug overexpressing cells regulates $\operatorname{Rad} 51$ mRNA stability. Notably, Rad51 down-regulation has been previously associated with increased breast cancer cell MSforming capability. ${ }^{17}$ Such knockdown was achieved through the overexpression of a hypoxia-inducible repressor of Rad51, ie, the polycomb receptor complex component $\mathrm{EZH} 2 .{ }^{17}$ We found that that EZH2 expression is increased in Slug overexpressing clones, as well as that EZH2 mRNA stability and protein level are reduced in $\beta$-catenin knockdown cells (Supplemental Figure S5, C-E). Following our additional observation that Brca1 mRNA half-life is reduced by $\beta$-catenin (Supplemental Figure S5F), we speculate that hypoxia operates on the CSCs' phenotype, not only by eliciting growth-promoting proinflammatory factors (including EZH2), ${ }^{46}$ but also by hampering the expression of proteins (including Brca1 and Rad51) that potentially restrain the onset of the CSCs phenotype. Because we show that another miR-221 target $(E R \alpha)$ is down-regulated by miR$221 / \beta$-catenin circuitry, the complex $\beta$-catenin-dependent reshape of gene expression is expected to generate a profile that is closely similar to the triple-negative/basal-like breast cancer. ${ }^{47}$ In such ER $\alpha$-negative tumors, the overexpression of a stem cell-like gene expression profile is accompanied by the down-regulation of Rad51 and the up-regulation of EZH2, miR-221, and $\gamma \mathrm{H} 2 \mathrm{AX}{ }^{48-50}$ In conclusion, these data support the notion that the CSCs' proinflammatory

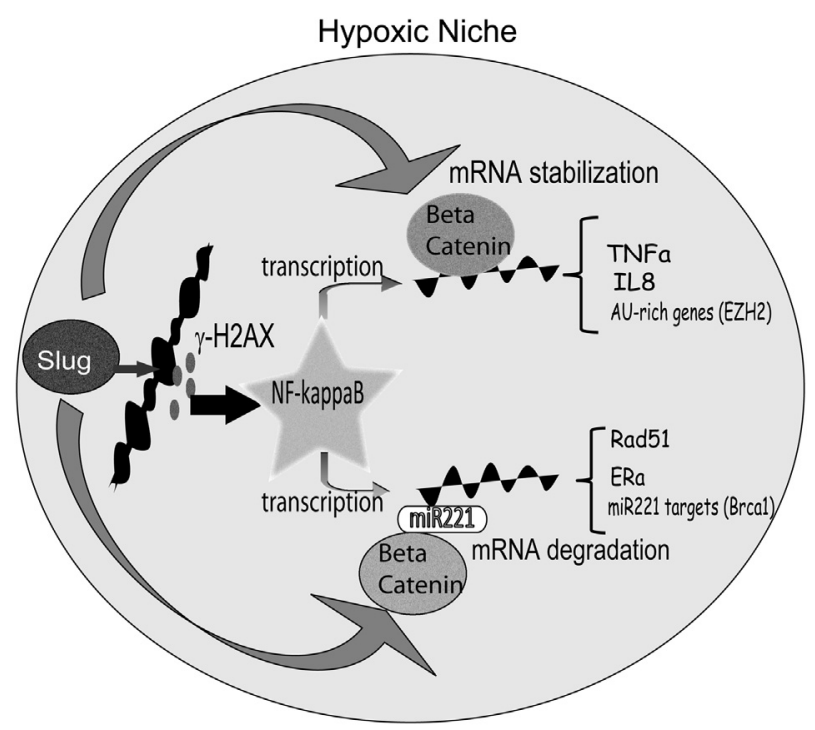

Figure 6 Scheme showing the sustenance of the CSC proinflammatory phenotype in a hypoxic environment. In the hypoxic niche, Slug triggers $\gamma-\mathrm{H} 2 \mathrm{AX}$ activation, which engenders NF- $\mathrm{B}$-mediated cytokine upregulation. Slug also induces $\beta$-catenin to bind cytoplasmic cytokine mRNAs, thus promoting their stabilization. Moreover, $\beta$-catenin binds miR221, and this phenomenon associates with enhanced mRNA degradation of miR221 targets, eg, Rad51and ER $\alpha$. Other potential adenylate uridylate (AU)-rich or miR-221 targets of such a mechanism, such as EZH2 and Brca1, are indicated. 
phenotype is sustained by a Slug/ $\beta$-catenin-driven molecular machinery (Figure 6) that operates at both the transcriptional and posttranscriptional levels to modulate mRNA stability in the hypoxic environment.

\section{Acknowledgments}

We thank Fondazione Carisbo and Fondazione del Monte for supporting the Center for Applied Biomedical Research (C.R.B.A.; St. Orsola-Malpighi University Hospital, Bologna, Italy).

G.S. and M.B. conceived and designed experiments; G.S., S.D.C., S.B., A.P., M.N., P.G., C.P., A.F., G.B., M.F., E.C., E.G., and M.D. performed the experiments; M.T., G.B., F.B., C.C., and D.S. provided material; M.B., G.S., M.D., M.F., and C.F. analyzed data; and M.B. and G.S. wrote the manuscript.

\section{Supplemental Data}

Supplemental material for this article can be found at http://dx.doi.org/10.1016/j.ajpath.2013.07.020.

\section{References}

1. Al-Hajj M, Wicha MS, Benito-Hernandez A, Morrison SJ, Clarke MF: Prospective identification of tumorigenic breast cancer cells. Proc Natl Acad Sci U S A 2003, 100:3983-3988

2. Konopleva MY, Jordan CT: Leukemia stem cells and microenvironment: biology and therapeutic targeting. J Clin Oncol 2011, 29: 591-599

3. Papi A, Storci G, Guarnieri T, De Carolis S, Bertoni S, Avenia N, Sanguinetti A, Sidoni A, Santini D, Ceccarelli C, Taffurelli M, Orlandi M, Bonafé M: Peroxisome proliferator activated receptor$\alpha /$ hypoxia inducible factor- $1 \alpha$ interplay sustains carbonic anhydrase IX and apolipoprotein E expression in breast cancer stem cells. PLoS One 2013, 8:e54968

4. Rajasekhar V, Studer L, Gerald W, Socci ND, Scher HI: Tumorinitiating stem-like cells in human prostate cancer exhibit increased NF-KB signaling. Nat Commun 2011, 2:162

5. Korkaya H, Liu S, Wicha MS: Breast cancer stem cells, cytokine networks, and the tumor microenvironment. J Clin Invest 2011, 121: 3804-3809

6. Sansone P, Storci G, Tavolari S, Guarnieri T, Giovannini C, Taffurelli M, Ceccarelli C, Santini D, Paterini P, Marcu KB, Chieco P, Bonafè M: IL-6 triggers malignant features in mammospheres from human ductal breast carcinoma and normal mammary gland. J Clin Invest 2007, 117:3988-4002

7. Storci G, Sansone P, Mari S, D’Uva G, Tavolari S, Guarnieri T, Taffurelli M, Ceccarelli C, Santini D, Chieco P, Marcu KB, Bonafè M: TNFalpha up-regulates SLUG via the NFkappaB/HIF1alpha axis, which imparts breast cancer cells with a stem cell-like phenotype. J Cell Physiol 2010, 225:682-691

8. Korkaya H, Kim GI, Davis A, Malik F, Henry NL, Ithimakin S, Quraishi AA, Tawakkol N, D'Angelo R, Paulson AK, Chung S, Luther T, Paholak HJ, Liu S, Hassan KA, Zen Q, Clouthier SG, Wicha MS: Activation of an IL6 inflammatory loop mediates trastuzumab resistance in HER2 + breast cancer by expanding the cancer stem cell population. Mol Cell 2012, 47:570-584

9. Prasad S, Ravindran J, Aggarwal BB: NF-kappaB and cancer: how intimate is this relationship. Mol Cell Biochem 2010, 336:25-37
10. Lee KE, Simon MC: From stem cells to cancer stem cells: HIF takes the stage. Curr Opin Cell Biol 2012, 24:232-235

11. Harrison H, Rogerson L, Gregson HJ, Brennan KR, Clarke RB, Landberg G: Contrasting hypoxic effects on breast cancer stem cell hierarchy is dependent on ER-a status. Cancer Res 2013, 73:1420-1433

12. Semenza GL: Hypoxia-inducible factors: mediators of cancer progression and targets for cancer therapy. Trends Pharmacol Sci 2012, 33:207-214

13. Seidel S, Garvalov BK, Wirta V, von Stechow L, Schänzer A, Meletis K, Wolter M, Sommerlad D, Henze AT, Nistér M, Reifenberger G, Lundeberg J, Frisén J, Acker T: A hypoxic niche regulates glioblastoma stem cells through hypoxia inducible factor 2 alpha. Brain 2010, 133:983-995

14. Hartkopf AD, Banys M, Krawczyk N, Staebler A, Becker S, Hoffmann J, Hahn M, Wallwiener M, Fehm T: Bone marrow versus sentinel lymph node involvement in breast cancer: a comparison of early hematogenous and early lymphatic tumor spread. Breast Cancer Res Treat 2012, 131:501-508

15. Lévesque JP, Helwani FM, Winkler IG: The endosteal 'osteoblastic' niche and its role in hematopoietic stem cell homing and mobilization. Leukemia 2010, 24:1979-1992

16. Bindra RS, Glazer PM: Repression of RAD51 gene expression by E2F4/p130 complexes in hypoxia. Oncogene 2007, 26:2048-2057

17. Chang CJ, Yang JY, Xia W, Chen CT, Xie X, Chao CH, Woodward WA, Hsu JM, Hortobagyi GN, Hung MC: EZH2 promotes expansion of breast tumor initiating cells through activation of RAF1- $\beta$-catenin signaling. Cancer Cell 2011, 19:86-100

18. Liu S, Ginestier C, Charafe-Jauffret E, Foco H, Kleer CG, Merajver SD, Dontu G, Wicha MS: BRCA1 regulates human mammary stem/progenitor cell fate. Proc Natl Acad Sci U S A 2008 , 105:1680-1685

19. Rodier F, Coppé JP, Patil CK, Hoeijmakers WA, Muñoz DP, Raza SR, Freund A, Campeau E, Davalos AR, Campisi J: Persistent DNA damage signalling triggers senescence-associated inflammatory cytokine secretion. Nat Cell Biol 2009, 11:973-979

20. McCool KW, Miyamoto S: DNA damage-dependent NF-кB activation: NEMO turns nuclear signaling inside out. Immunol Rev 2012, 246:311-326

21. Niu J, Shi Y, Tan G, Yang CH, Fan M, Pfeffer LM, Wu ZH: DNA damage induces NF- $\mathrm{BB}$-dependent microRNA-221 up-regulation and promotes breast cancer cell invasion. J Biol Chem 2012, 287: 21783-21795

22. Scheel C, Eaton EN, Li SH, Chaffer CL, Reinhardt F, Kah KJ, Bell G, Guo W, Rubin J, Richardson AL, Weinberg RA: Paracrine and autocrine signals induce and maintain mesenchymal and stem cell states in the breast. Cell 2011, 145:926-940

23. Bhat-Nakshatri P, Appaiah H, Ballas C, Pick-Franke P, Goulet R Jr., Badve S, Srour EF, Nakshatri H: SLUG/SNAI2 and tumor necrosis factor generate breast cells with CD44+/CD24- phenotype. BMC Cancer 2010, 10:411

24. Storci G, Sansone P, Trere D, Tavolari S, Taffurelli M, Ceccarelli C, Guarnieri T, Paterini P, Pariali M, Montanaro L, Santini D, Chieco P, Bonafé M: The basal-like breast carcinoma phenotype is regulated by SLUG gene expression. J Pathol 2008, 214:25-37

25. Pérez-Caro M, Bermejo-Rodríguez C, González-Herrero I, SánchezBeato M, Piris MA, Sánchez-García I: Transcriptomal profiling of the cellular response to DNA damage mediated by Slug (Snai2). Br J Cancer 2008, 98:480-488

26. Ikuta T, Kawajiri K: Zinc finger transcription factor Slug is a novel target gene of aryl hydrocarbon receptor. Exp Cell Res 2006, 312: 3585-3594

27. Proia TA, Keller PJ, Gupta PB, Klebba I, Jones AD, Sedic M, Gilmore H, Tung N, Naber SP, Schnitt S, Lander ES, Kuperwasser C: Genetic predisposition directs breast cancer phenotype by dictating progenitor cell fate. Cell Stem Cell 2011, 8:149-163

28. Guo W, Keckesova Z, Donaher JL, Shibue T, Tischler V, Reinhardt F, Itzkovitz S, Noske A, Zürrer-Härdi U, Bell G, Tam WL, Mani SA, van 
Oudenaarden A, Weinberg RA: Slug and Sox9 cooperatively determine the mammary stem cell state. Cell 2012, 148:1015-1028

29. Rogakou EP, Pilch DR, Orr AH, Ivanova VS, Bonner WM: DNA double stranded breaks induce histone H2AX phosphorylation on serine 139. J Biol Chem 1998, 273:5858-5868

30. Korkaya H, Paulson A, Charafe-Jauffret E, Ginestier C, Brown M, Dutcher J, Clouthier SG, Wicha MS: Regulation of mammary stem/progenitor cells by PTEN/Akt/beta-catenin signaling. PLoS Biol 2009, 7:e1000121

31. Kim I, Kwak H, Lee HK, Hyun S, Jeong S: $\beta$-Catenin recognizes a specific RNA motif in the cyclooxygenase-2 mRNA $3^{\prime}$-UTR and interacts with HuR in colon cancer cells. Nucleic Acids Res 2012, 40: 6863-6872

32. Galardi S, Mercatelli N, Farace MG, Ciafrè SA: NF-kB and c-Jun induce the expression of the oncogenic miR-221 and miR-222 in prostate carcinoma and glioblastoma cells. Nucleic Acids Res 2011, 39:3892-3902

33. Stinson S, Lackner MR, Adai AT, Yu N, Kim HJ, O'Brien C, Spoerke J, Jhunjhunwala S, Boyd Z, Januario T, Newman RJ, Yue P, Bourgon R, Modrusan Z, Stern HM, Warming S, de Sauvage FJ, Amler L, Yeh RF, Dornan D: miR-221/222 targeting of trichorhinophalangeal 1 (TRPS1) promotes epithelial-to-mesenchymal transition in breast cancer. Sci Signal 2011, 4(186):pt5

34. Krejci L, Altmannova V, Spirek M, Zhao X: Homologous recombination and its regulation. Nucleic Acids Res 2012, 40:5795-5818

35. Tenenbaum SA, Lager PJ, Carson CC, Keene JD: Ribonomics: identifying mRNA subsets in mRNP complexes using antibodies to RNAbinding proteins and genomic arrays. Methods 2002, 26:191-198

36. Heinonen M, Hemmes A, Salmenkivi K, Abdelmohsen K, Vilén ST, Laakso M, Leidenius M, Salo T, Hautaniemi S, Gorospe M, Heikkilä P, Haglund C, Ristimäki A: Role of RNA binding protein HuR in ductal carcinoma in situ of the breast. J Pathol 2011, 224: $529-539$

37. Lambertini E, Lolli A, Vezzali F, Penolazzi L, Gambari R, Piva R: Correlation between Slug transcription factor and miR-221 in MDAMB-231 breast cancer cells. BMC Cancer 2012, 12:445

38. Rao X, Di Leva G, Li M, Fang F, Devlin C, Hartman-Frey C, Burow ME, Ivan M, Croce CM, Nephew KP: MicroRNA-221/222 confers breast cancer fulvestrant resistance by regulating multiple signaling pathways. Oncogene 2011, 30:1082-1097

39. Asiedu MK, Ingle JN, Behrens MD, Radisky DC, Knutson KL: TGFbeta/TNFalpha-mediated epithelial-mesenchymal transition generates breast cancer stem cells with a claudin-low phenotype. Cancer Res 2011, 71:4707-4719

40. Yin X, Wolford CC, Chang YS, McConoughey SJ, Ramsey SA, Aderem A, Hai T: ATF3, an adaptive-response gene, enhances TGF \{beta\} signaling and cancer-initiating cell features in breast cancer cells. J Cell Sci 2010, 123:3558-3565

41. Andäng M, Hjerling-Leffler J, Moliner A, Lundgren TK, CasteloBranco G, Nanou E, Pozas E, Bryja V, Halliez S, Nishimaru H, Wilbertz J, Arenas E, Koltzenburg M, Charnay P, El Manira A, Ibañez CF, Ernfors P: H2AX-dependent GABA(A) receptor regulation of stem cell proliferation. Nature 2008, 451:460-464

42. Economopoulou M, Langer HF, Celeste A, Orlova VV, Choi EY, Ma M, Vassilopoulos A, Callen E, Deng C, Bassing CH, Boehm M, Nussenzweig A, Chavakis T: Histone H2AX is integral to hypoxiadriven neovascularization. Nat Med 2009, 15:553-558

43. Gorospe M, Tominaga K, Wu X, Fahling M, Ivan M: Post-transcriptional control of the hypoxic response by RNA-binding proteins and microRNAs. Front Mol Neurosci 2011, 4:7

44. Anson M, Crain-Denoyelle AM, Baud V, Chereau F, Gougelet A, Terris B, Yamagoe S, Colnot S, Viguier M, Perret C, Couty JP: Oncogenic $\beta$-catenin triggers an inflammatory response that determines the aggressiveness of hepatocellular carcinoma in mice. J Clin Invest 2012, 122:586-599

45. Wu ZQ, Li XY, Hu CY, Ford M, Kleer CG, Weiss SJ: Canonical Wnt signaling regulates Slug activity and links epithelial-mesenchymal transition with epigenetic Breast Cancer 1, Early Onset (BRCA1) repression. Proc Natl Acad Sci U S A 2012, 109:16654-16659

46. Lee ST, Li Z, Wu Z, Aau M, Guan P, Karuturi RK, Liou YC, Yu Q: Context-specific regulation of $\mathrm{NF}-\mathrm{\kappa B}$ target gene expression by EZH2 in breast cancers. Mol Cell 2011, 43:798-810

47. Penault-Llorca F, Viale G: Pathological and molecular diagnosis of triple-negative breast cancer: a clinical perspective. Ann Oncol 2012, 6:vi19-22

48. Scully R, Chen J, Ochs RL, Keegan K, Hoekstra M, Feunteun J, Livingston DM: Dynamic changes of BRCA1 subnuclear location and phosphorylation state are initiated by DNA damage. Cell 1997, 90:425-435

49. Nagelkerke A, Van Kuijk SJ, Sweep FC, Nagtegaal ID, Hoogerbrugge N, Martens JW, Timmermans MA, van Laarhoven HW, Bussink J, Span PN: Constitutive expression of $\gamma-\mathrm{H} 2 \mathrm{AX}$ has prognostic relevance in triple negative breast cancer. Radiother Oncol 2011, 101:39-45

50. Barbano R, Copetti M, Perrone G, Pazienza V, Muscarella LA, Balsamo T, Storlazzi CT, Ripoli M, Rinaldi M, Valori VM, Latiano TP, Maiello E, Stanziale P, Carella M, Mangia A, Pellegrini F, Bisceglia M, Muda AO, Altomare V, Murgo R, Fazio VM, Parrella P: High RAD51 mRNA expression characterize estrogen receptor-positive/progesterone receptor-negative breast cancer and is associated with patient's outcome. Int J Cancer 2011, 129:536-545 